\title{
Implementasi Pembelajaran Dalam Jaringan (Daring) pada Mata Pelajaran Matematika di SMA Veteran 1 Sukoharjo
}

Author:
Sarifah Fadilah ${ }^{1}$
Herry Agus Susanto $^{2}$
Andhika Ayu Wulandari $^{3}$
Affiliation:
1,2,3University of Veteran
Bangun Nusantara, Central
Java, Indonesia
Corresponding author:
Sarifah Fadilah,
sarifahfadilah94@gamil.com
Dates:
Received: $15 / 10 / 2021$
Accepted: $20 / 11 / 2021$
Published: $30 / 11 / 2021$

\begin{abstract}
Abstrak. Penelitian ini dilaksanakan di SMA Veteran 1 Sukoharjo, dengan tujuan untuk mengetahui penerapan pembelajaran daring dan faktor yang mempengaruhinya. Penelitian ini termasuk penelitian deskriptif dengan pendekatan kualitatif.. Subjek penelitiannya yaitu wakil kepala sekolah bagian kurikulum, guru matematika, dan siswa kelas XI MIPA 1. Teknik pengumpulan data dengan menggunakan observasi, wawancara, dan dokumentasi. Hasil penelitian yaitu pembelajaran daring menggunakan RPP daring 1 lembar, memanfaatkan google classroom, dengan tahapan pembelajarannya presensi, penyampaian materi, latihan soal/tugas. Siswa dan guru mendapatkan kuota internet dari pemerintah, dan disediakan wifi di sekolah. Aspek penilaiannya yaitu kognitif, keterampilan, dan sikap. Faktor yang mendukung yaitu peran orang tua, ketersediaan sarana dan prasarana, dan semangat belajar, sedangkan yang menghambat yaitu tidak tersedianya handphone, kuota, dan jaringan internet.
\end{abstract}

Kata kunci: implementasi, daring, covid-19

\begin{abstract}
This research was conducted at SMA Veteran 1 Sukoharjo, with the aim of knowing the application of online learning and the factors that influence it. This research includes descriptive research with a qualitative approach. The research subjects are the vice principal of the curriculum section, mathematics teachers, and students of class XI MIPA 1. Data collection techniques using observation, interviews, and documentation. The results of the research are online learning using 1 sheet of online lesson plans, utilizing google classroom, with the stages of learning attendance, delivery of material, practice questions / assignments. Students and teachers get internet quota from the government, and wifi is provided in schools. Aspects of the assessment are cognitive, skills, and attitudes. The supporting factors are the role of parents, the availability of facilities and infrastructure, and the spirit of learning, while the inhibiting factors are the unavailability of mobile phones, quotas, and internet networks.
\end{abstract}

Keywords: implementation, online, covid-19

\section{JoMEaL}

Copyright:

This work is licensed under a Creative Commons Attribution-ShareAlike 4.0 International License.

Read online:

https://jurnal.unej.ac.id/index.php/JOMEAL/index or scan barcode beside.

How to cite this article:

Fadilah, S., Susanto, H., \& Wulandari, A. (2021). Implementasi Pembelajaran Dalam Jaringan (Daring) pada Mata Pelajaran Matematika di SMA Veteran 1 Sukoharjo. Journal of Mathematics Education and Learning, 1(3), 218-224. doi:10.19184/jomeal.v1i3.26774 


\section{Pendahuluan}

Pendidikan merupakan suatu proses individu untuk mengembangkan potensi dirinya untuk menjadi lebih baik. Dengan adanya pendidikan seseorang dapat memiliki kecerdasan, keterampilan, serta kepribadian yang baik, yang dapat bermanfaat bagi dirinya sendiri maupun masyarakat sekitar. Salah satu bentuk pendidikan formal yaitu kegiatan pembelajaran di sekolah. Pembelajaran dilakukan dengan tahap perencanaan, pelaksanaan, dan evaluasi oleh pendidik kemudian diaplikasikan melalui pertemuan klasikal dengan didukung media, alat, dan bahan yang sesuai (Syarifudin, 2020).

Dunia pendidikan nampak berbeda pada saat ini, dengan munculnya wabah penyakit Corona virus 2019 (COVID-19) yang menyebar hampir di seluruh negara, tidak terkecuali di Indonesia. Wabah penyakit ini disebabkan oleh virus corona yang pertama kali diidentifikasi di Wuhan, China. Penyakit COVID-19 adalah penyakit menular yang disebabkan oleh sindrom pernapasan akut corona virus 2 (SARS-CoV-2) (Siahaan, 2020). Hanya dalam waktu yang singkat penyakit ini telah tersebar luas, bahkan sampai merenggut banyak nyawa di berbagai negara. Akibat dari pandemi ini beberapa negara mempunyai kebijakan guna menekan penyebaran virus covid-19, begitu juga di Indonesia. Pemerintah telah menentukan kebijakan Belajar dari Rumah (BDR) sesuai dengan Surat Edaran Nomor 4 Tahun 2020 tentang Pelaksanaan Kebijakan Pendidikan dalam Masa Darurat Penyebaran Coronavirus Disease (COVID-19). Hal ini mengakibatkan pendidikan di Indonesia tidak dapat dilaksanakan seperti sebelumnya. Kegiatan belajar mengajar selama pandemi covid-19 dilaksanakan secara daring (dalam jaringan) dengan memanfaatkan koneksi internet.

Pembelajaran daring dapat dikatakan sebagai sebuah pembelajaran yang dilakukan secara jarak jauh dengan bantuan media berupa internet dan alat penunjang lainnya, seperti telepon seluler dan komputer. Sistem pembelajaran daring ini telah diterapkan di Indonesia, begitu juga di Kabupaten Sukoharjo. Salah satu pelaksana pembelajaran daring yaitu di SMA Veteran 1 Sukoharjo. Pembelajaran daring dapat dilaksanakan di manapun dan kapanpun tidak harus berada dalam satu tempat, selama adanya koneksi internet untuk menunjang kegiatan ini. Pembelajaran daring dapat dilaksanakan dengan memanfaatkan media yang ada, seperti google classroom, google meet, zoom meeting, spada, dan masih banyak media yang lain. Proses pembelajaran daring memang terlihat mudah untuk dilaksanakan, namun banyak sekali faktor yang berpengaruh agar proses pembelajaran daring dapat berjalan dengan lancar sesuai harapan para guru.

Dalam pembelajaran daring guru sangat berperan penting dalam menyukseskan kegiatan belajar mengajar. Guru diharapkan memiliki inovasi untuk menciptakan kegiatan pembelajaran secara daring yang efektif, efisien, dan tidak membosankan bagi siswa. Siswa sering merasa bosan ketika pembelajaran tidak dilaksanakan secara tatap muka. Selain itu, siswa juga merasa kesulitan untuk memahami materi-materi yang disampaikan guru terutama pada mata pelajaran yang dianggap sulit, seperti matematika. Matematika merupakan mata pelajaran wajib bagi peserta didik yang berhubungan dengan mata pelajaran yang lain. Matematika adalah suatu disiplin ilmu yang sistematis yang menelaah pola hubungan, pola berfikir, seni, dan bahasa yang semuanya dikaji dengan logika serta bersifat deduktif, matematika berguna untuk membantu manusia dalam memahami dan menguasai persoalan sosial, ekonomi, dan alam (Fahrurrozi \& Hamdi, 2017). Dalam pembelajaran daring khususnya mata pelajaran matematika guru harus menentukan model dan media pembelajaran yang tepat untuk digunakan selama proses belajar mengajar. Guru juga harus dapat menciptakan pembelajaran daring matematika yang menyenangkan dan mudah dipahami agar siswa tidak merasa pembelajaran matematika semakin sulit jika dilaksanakan secara daring. 
Implementasi adalah tindakan yang dilakukan setelah suatu kebijakan ditetapkan, implementasi merupakan cara agar sebuah kebijakan dapat mencapai tujuan yang telah ditetapkan (Simarmata, 2015). Menurut Undang-undang Nomor 20 tahun 2003 pembelajaran adalah suatu proses interaksi peserta didik dengan pendidik dan sumber belajar pada suatu lingkungan belajar. Menurut Basri (2015), pembelajaran adalah seluruh mekanisme dan proses belajar yang dilaksanakan oleh para pendidik terhadap peserta didik dengan melibatkan seluruh komponen pembelajaran untuk mendukung tercapainya tujuan belajar. Implementasi pembelajaran dapat dikatakan sebagai suatu proses dalam kegiatan belajar meliputi perencanaan, pelaksanaan, serta penilaian untuk mencapai tujuan belajar yang telah disusun secara terperinci.

Penelitian ini dilakukan di kelas XI MIPA 1 SMA Veteran 1 Sukoharjo pada mata pelajaran matematika, dengan tujuan untuk mengetahui bagaimana penerapan pembelajaran daring matematika di kelas tersebut mulai dari perencanaan, pelaksanaan, penilaian, serta faktor-faktor yang mempengaruhi terlaksanya pembelajaran daring. Pembelajaran matematika di kelas tersebut memanfaatkan google classroom dalam pembelajarannya baik untuk matematika wajib maupun peminatan. Manfaat dari penelitian ini diharapkan dapat memberikan gambaran mengenai penerapan pembelajaran daring yang kedepannya dapat dilaksanakan lebih baik dan efektif, selain itu dapat digunakan sebagai saran dan masukan bagi guru agar lebih kreatif dan inovatif dalam melaksanakan pembelajaran daring. Relevansi penenilitian ini dari penelitian sebelumnya yaitu dalam penelitian ini selain penerapan pembelajaran daring peneliti juga meneliti mengenai faktor yang mempengaruhi pembelajaran daring, baik faktor pendukung maupun penghambat.

\section{Metode Penelitian}

Penelitian ini dilakukan menggunakan penelitian deskriptif, dengan menggunakan pendekatan penelitian kualitatif. Menurut Arikunto (2013), penelitian deskriptif adalah penelitian yang dimaksudkan untuk menyelidiki keadaan, kondisi atau hal lain-lain yang sudah disebutkan, yang hasilnya dipaparkan dalam bentuk laporan penelitian. Menurut Gunawan (2016), penelitian kualitatif adalah penelitian yang bertujuan untuk mendapatkan pemahaman yang mendalam tentang masalahmasalah menusia dan sosial, bukan mendeskripsikan bagian permukaan dari suatu realitas sebagaimana dilakukan penelitian kuantitatif dengan positivismenya. Menurut Kriyantono dalam (Akhmad, 2015), penelitian deskriptif kualitatif yaitu suatu teknik yang menggambarkan dan menginterpretasikan arti data-data yang telah terkumpul dengan memberikan perhatian dan merekam sebanyak mungkin aspek situasi yang diteliti pada saat itu, sehingga memperoleh gambaran secara umum dan menyeluruh tentang keadaan sebenarnya. Penelitian ini akan mendeskripsikan mengenai penerapan pembelajaran daring di SMA Veteran 1 Sukoharjo mulai dari perencanaan, pelaksanaan, dan penilaian, serta faktor-faktor yang mempengaruhi proses pembelajaran daring.

Subjek dalam penelitian ini yaitu wakil kepala sekolah bagian kurikulum, guru mata pelajaran matematika, serta 3 siswa kelas XI MIPA 1 yang dipilih melalui undian. Teknik pengumpulan data yang digunakan yaitu dengan observasi, wawancara, dan dokumentasi. Observasi merupakan pengamatan secara langsung pada objek penelitian dengan menggunakan seluruh alat indra yang dilakukan untuk mengumpulkan data yang dapat digunakan sebagai pemecahan permasalahan. Dengan observasi peneliti dapat mendokumentasikan dan merefleksi secara sistematis terhadap kegiatan dan interaksi subjek peneliti. Observasi yang dilakukan oleh peneliti yaitu dengan mengamati kegiatan pembelajaran yang dilaksanakan secara daring pada mata pelajaran matematika 
di SMA Veteran 1 Sukoharjo, kemudian mendokumentasi kegiatan untuk memperoleh data yang dibutuhkan dalam penelitian ini.

Metode analisis data merupakan upaya mencari dan menata secara sistematis dari hasil observasi, wawancara, dan dokumentasi untuk meningkatkan pemahaman penelitian terhadap kasus yang diteliti dan menyajikannya sebagai temuan bagi orang lain (Purwati \& Nugroho, 2017). Miles dan Huberman (dalam Gunawan, 2016), mengemukakan tiga tahapan yang harus dikerjakan dalam menganalisis data penelitian kualitatif, yaitu reduksi data, paparan data, dan penarikan kesimpulan atau verifikasi.

Penelitian ini menggunakan triangulasi sumber untuk mengecek keabsahan data. Triangulasi sumber untuk mendapatkan data dari sumber yang berbeda-beda dengan teknik yang sama (Hidayati \& Septiani, 2015). Sumber penelitian ini berasal dari wakil kepala sekolah bagian kurikulum, guru mata pelajaran matematika, dan 3 siswa kelas XI MIPA 1 SMA Veteran 1 Sukoharjo.

\section{Hasil dan Pembahasan}

Penerapan pembelajaran daring di kelas XI MIPA 1 SMA Veteran 1 Sukoharjo meliputi perencanaan, pelaksanaan, dan penilaian. Perencanaan pembelajaran daring menggunakan rencana pelaksanaan pembelajaran (RPP) daring satu lembar. Perencanaan mengandung rangkaian-rangkaian putusan yang luas dan penjelasan-penjelasan dari tujuan, penentuan kebijakan, penentuan program, penentuan metode-metode dan prosedur tertentu dan penentuan kegiatan berdasarkan jadwal seharihari (Ananda, 2019). Pedoman atau prosedur dari sekolah dalam pelaksanaan pembelajaran daring yaitu dimulai dengan presensi, pemberian materi, dan dilanjutkan dengan latihan soal/tugas. Selain itu, sekolah juga membekali guru-guru mengenai bagaimana cara mengoperasikan aplikasi-aplikasi yang dapat digunakan dalam pembelajaran daring, hal ini dimaksudkan agar pembelajaran daring dapat berjalan lancer dan efektif. Pembelajaran daring matematika memanfaatkan aplikasi google classroom, dengan media pembelajaran berupa power point, link youtube dan google, serta materi dalam bentuk pdf. Menurut Sanaky (dalam Wulandari et al., 2017), media pembelajaran untuk merangsang siswa dalam belajar salah satunya dengan memberi suasana belajar yang tidak tertekan, santai dan menarik sehingga dapat mencapai tujuan pembelajaran.

Kelancaran pelaksanaan pembelajaran daring dipengaruhi oleh banyak faktor, salah satunya yaitu ketersediaan sarana dan prasarana. Hal tersebut selaras dengan pendapat Handarini \& Wulandari (2020), untuk melakukan pembelajaran daring diperlukan sarana dan prasarana yang memadai, misalnya jaringan internet, smartphone, laptop maupun komputer. Sarana dan prasarana yang diperoleh dari pemerintah untuk guru dan siswa yaitu berupa bantuan kuota internet, bantuan ini sangat membantu dalam pelaksanaan pembelajaran daring baik bagi siswa maupun guru. Akan tetapi bantuan tersebut hanya beberapa kali saja, sehingga saat ini siswa merasa keberatan dalam melaksanakan pembelajaran daring karena harus membeli kuota internet sendiri, selain itu siswa juga berharap untuk mendapatkan bantuan kuota internet lagi dari pemerintah/sekolah. Selain dari pemerintah, sekolah juga memberikan sarana dan prasarana berupa wifi di sekolah. Guru dan siswa yang benar-benar membutuhkan diizinkan untuk datang ke sekolah untuk memanfaatkan wifi yang ada. Pihak sekolah memberikan batasan dalam pemanfaatan wifi, yaitu dalam satu ruangan tertentu hanya diperbolehkan untuk ditempati maksimal 8 orang, hal ini bertujuan untuk mengurangi adanya kerumunan guna memutus mata rantai penyebaran covid-19. Tahapan dalam pelaksanaan pembelajaran daring di kelas XI MIPA 1 sudah sesuai dengan pedoman dari sekolah. Tahapannya 
yaitu guru melakukan presensi, lalu pemberian materi melalui aplikasi dengan media yang sudah dipilih oleh guru. Selanjutnya yaitu pemberian soal untuk latihan mandiri ataupun tugas harian untuk dikumpulkan. Meskipun tugas tidak diberikan setiap pembelajaran, namun ada beberapa siswa yang tidak mengumpulkan tugas sesuai dengan batas waktu yang ditentukan. Hal ini dikarenakan ada siswa yang bekerja, selain itu siswa juga merasakan kesulitan dalam mengerjakan soal yang menjadikan siswa menjadi bermalas-malasan dalam pembelajaran daring ini. Permasalahan ini mengharuskan guru mata pelajaran untuk dapat menciptakan pembelajaran yang efektif dan menyenangkan bagi siswa.

Guru matematika sendiripun memiliki inisiatif tersendiri dalam menciptakan pembelajaran agar tidak membosankan. Bentuk penugasan yang diberikan tidak selalu berupa pengerjaan soal agar siswa tidak selalu merasakan bahwa pembelajaran daring matematika sulit, terkadang guru meminta siswa untuk membuat rangkuman materi yang ada kaitannya dengan materi yang pernah dipelajari sebelumnya, hal ini bertujuan agar siswa dapat flashback untuk mengingat-ingat materi tersebut sehingga akan memudahkan dalam proses pembelajaran. Penilaian pembelajaan daring diambil dari kegiatan harian, penugasan, serta nilai ujian. Aspek penilaiannya yaitu aspek kognitif, keterampilan dan sikap. Aspek kognitif dan keterampilan dilihat dari ujian maupun penugasan disetiap pembelajaran, sedangkan aspek sikap dilihat dari penggunaan bahasa dalam berkomunikasi saat pembelajaran. Bentuk soal dalam ujian yaitu pilihan ganda yang dilaksanakan secara daring menggunakan google form, akan tetapi guru selalu meminta hasil coretan siswa yang dikirimkan mealui whatsapp untuk mengetahui apakah siswa benar-benar mengerjakan atau hanya asal menjawab. Akan tetapi bentuk soal pada tugas atau ulangan harian yaitu dalam bentuk essay. Proses penilaian tidak hanya berdasarkan nilai ujian saja, guru juga mempertimbangkan dari nilai tugas yang lain, dan juga keaktifan harian siswa.

Berdasar hasil wawancara, terdapat dua faktor yang mempengaruhi kegiatan pembelajaran daring di kelas XI MIPA 1 yaitu faktor pendukung dan faktor penghambat. Faktor pendukung dalam pembelajaran daring yaitu pemilihan aplikasi dan media yang tepat sehingga dapat menciptakan pembelajaran yang efektif dan menyenangkan. Tingginya semangat belajar siswa serta guru yang selalu memberi semangat kepada siswa, akan menjadikan siswa lebih termotivasi untuk belajar. Siswa yang mempunyai motivasi yang tinggi juga akan mempunyai banyak energi untuk melakukan kegiatan belajar (Mz \& Hamid, 2020). Ketersediaan handphone, kuota, dan jaringan internet juga sangat mendukung terlaksananya pembelajaran daring. Kegiatan pembelajaran daring yang dilakukan di rumah, sangat membutuhkan peran keluarga, sebagai contoh untuk selalu mengingatkan kapan waktu mereka belajar, dan kapan untuk bermain. Selain itu ketika siswa merasa kesulitan, keluarga juga dapat membantu proses belajar mereka. Kemudahan akses internet ketika pembelajaran daring, juga dapat menjadi alternatif siswa ketika merasa kesulitan dalam proses pembelajaran. Faktor penghambat dalam pembelajaran daring antara lain lokasi rumah siswa yang pelosok sehingga tidak adanya jaringan internet di rumahnya. Hal ini sangat menghambat kelancaran proses pembelajaran daring yang sangat membutuhkan jaringan internet. Kondisi ekonomi keluarga siswa yang tidak semua mampu, mengakibatkan ada beberapa siswa yang tidak memiliki handphone sehingga harus bergantian dengan orangtuanya, maka siswa baru dapat mengikuti pembelajaran di sore hari. Hal ini selaras dengan pendapat Novita (2020), pembelajaran sistem daring yang memerlukan perangkat teknologi gadget menjadi persoalan jika satu keluarga memiliki sejumlah anak yang tersebar di semua jenjang pendidikan, sementara penghasilan keluarga terbatas. Maka itu, tentu sistem daring akan 
sangat memberatkan bagi keluarga siswa, terutama bagi keluarga yang memiliki lebih dari satu anak yang masih sekolah dan anak-anak tersebut membutuhkan gadget masing-masing untuk pembelajaran. Selain gadget, kuota internet yang terbilang cukup mahal juga menghambat proses pembelajaran daring bagi siswa yang penghasilan keluarganya terbatas. Subsidi melalui bebas kuota bagi keluarga seperti ini sangat membantu meringankan beban mereka. Pembelajaran yang dilaksanakan secara daring menjadikan siswa kesulitan dalam memahami materi pembelajaran matematika, sehingga mengakibatkan kegiatan pembelajaran daring matematika kurang maksimal. Selain itu, hasil observasi di google classroom dalam pelaksanaan pembelajaran daring kurang adanya interaksi antara guru dan siswa selama proses pembelajaran berlangsung, serta siswa tidak aktif ketika pembelajaran berlangsung.

Berdasarkan perbandingan hasil wawancara dengan kelima subjek penelitian pada perencanaan pembelajaran daring empat subjek mengatakan hal serupa, yaitu penggunaan aplikasi google classroom, dengan media pembelajaran berupa powerpoint, LKS, link youtube dan google, sedangkan satu subjek yang mengatakan bahwa media yang digunakan yaitu e-learning berbasis schoology. Pelaksanaan pembelajaran daring mengenai sarana dan prasarana kelima subjek mengatakan bahwa mereka mendapatkan bantuan kuota internet dari pemerintah dan disediakan wifi di sekolah, sedangkan untuk tahap pembelajaran ada dua subjek mengatakan hal berbeda, subjek 4 mengatakan tidak adanya presensi sebelum pembelajaran, subjek 5 mengatakan tahapan pembelajaran hanya mempersiapkan diri dan mempelajari materi, dan lainnya mengatakan tahapan pembelajaran meliputi presensi, pemberian materi, lalu latihan soal/tugas. Penilaian pembelajaran daring yang meliputi bagaimana proses ujian dan bentuk penugasan, keempat subjek mengatakan bahwa ujian dilaksanakan secara daring dengan bentuk soal pilihan ganda, dan bentuk penugasan yaitu mengerjakan soal-soal, sedangkan mengenai aspek penilaian yang diambil subjek 1 dan subjek 2 mengatakan bahwa penilaian diambil dari keaktifan, nilai harian, dan nilai ujian. Faktor pendukung dan penghambat kegiatan daring kelima subjek memiliki pendapat yang hampir sama satu sama lain, yaitu mengenai peran orang tua, semangat belajar siswa, ketersediaan handphone, kuota, dan jaringan internet.

\section{Kesimpulan}

Berdasarkan hasil dan pembahasan tersebut dapat disimpulkan bahwa penerapan pembelajaran pembelajaran di kelas XI MIPA 1 SMA Veteran 1 Sukoharjo sudah terlaksana dengan baik dan terstruktur. Persiapan guru dan siswa dalam pembelajaran daring sudah dimaksimalkan. Pelaksanaan pembelajaran daring sesuai dengan perencanaan yang sudah dibuat. Meski demikian dalam pelaksanaan pembelajaran daring ini tidak selalu berjalan seperti yang diharapkan. Terdapat faktor pendukung dan penghambat daam pembelajaran daring yaitu ketersediaan gadget, kuota, serta jaringan internet.

\section{Daftar Pustaka}

Akhmad, K. A. (2015). Pemanfaatan Media Sosial bagi Pengembangan Pemasaran UMKM (Studi Deskriptif Kualitatif pada Distro di Kota Surakarta). Duta.Com, 9(September), 43-54. http://journal.stmikdb.ac.id/index.php/dutacom/article/view/17

Ananda, R. (2019). Dr. Rusydi Ananda, M.Pd. 
Arikunto, S. (2013). Prosedur Penelitian: Suatu Pendekatan Praktik. Rineka Cipta.

Basri, H. (2015). Paradigma Baru Sistem Pembelajaran. CV Pustaka Setia.

Fahrurrozi, \& Hamdi, S. (2017). Metode Pembelajaran Matematika. Universitas Hamzanwadi Press.

Gunawan, I. (2016). Metode Penelitian Kualitatif: Teori dan Praktik. PT Bumi Aksara.

Handarini, O. I., \& Wulandari, S. S. (2020). Pembelajaran Daring Sebagai Upaya Study From Home (SFH) Selama Pandemi Covid-19. Family Practice, 8(3), 496-503. https://doi.org/10.1093/fampra/cmy005

Hidayati, Y. M., \& Septiani, T. (2015). Studi kesiapan guru melaksanakan kurikulum 2013 dalam pembelajaran berbasis tematik integratif di sekolah dasar se kecamatan colomadu tahun ajaran 2014/2015. Profesi Pndidikan Dasar, 2, 49-58.

Mz, A. B., \& Hamid, A. (2020). Jurnal Pendidikan Islam Vol. 8 No.3 Januari-Juni 2020. 8(3), 114.

Novita, H. (2020). Plus Minus Penggunaan Aplikasi-Aplikasi Pembelajaran Daring Selama Pandemi Covid-19. Unimed Medan, June, 1-11. https://www.researchgate.net/profile/DianaNovita/publication/341830562

Purwati, H., \& Nugroho, A. A. (2017). Analisis Kemampuan Komunikasi Matematis Mahasiswa Dalam Menyelesaikan Masalah Pada Mata Kuliah Program Linear. JIPMat, 1(2), 127-134. https://doi.org/10.26877/jipmat.v1i2.1239

Siahaan, M. (2020). Dampak Pandemi Covid-19 Terhadap Dunia Pendidikan. Jurnal Kajian Ilmiah, 1(1), 73-80. https://doi.org/10.31599/jki.v1i1.265

Simarmata, Y. M. U. (2015). Implementasi Kebijakan Pelarangan dan Penghapusan Bentuk-Bentuk Pekerjaan Terburuk Bagi Pekerja Anak di Kota Bandung. 3-15.

Syarifudin, A. S. (2020). Impelementasi Pembelajaran Daring Untuk Meningkatkan Mutu Pendidikan Sebagai Dampak Diterapkannya Social Distancing. Jurnal Pendidikan Bahasa Dan Sastra Indonesia Metalingua, 5(1), 31-34. https://doi.org/10.21107/metalingua.v5i1.7072

Wulandari, A. A., Astutiningtyas, E. L., \& Susilowati, D. (2017). Penggunaan Magic Button Sebagai Media Pembelajaran Operasi Bilangan Bulat. JP2M (Jurnal Pendidikan Dan Pembelajaran Matematika), 2(2), 25. https://doi.org/10.29100/jp2m.v2i2.203 